\title{
Analisis Efficient Market Hypothesis (EMH) di Bursa Saham Syariah, 2005:1 - 2008:11
}

\author{
Oleh: Malik Cahyadin \& Devi Oktaviana Milandari ${ }^{1}$
}

\begin{abstract}
Abstraks
Study on sharia stocks exchange takes an important place and consideration since transactions and financial activities within a stocks exchange market will determine the mode of market itself and will have impact on economic activities in a country where the market is established. This paper is mainly focused to oversee sharia stocks exchanges in Indonesia, United States, Saudi Arabia, and Malaysia using efficient market hypothesis (EHM) method. Data used in this study were collected from monthly sharia stocks exchanges index from 2005:1 to 2008:11. There are three types of market in EHM method, i.e. weak, least-strong, and strong market. Econometric test procedures used in this study involve data stationery and Granger causality tests. Data stationery test indicates that all variables are stationer at first difference, I(1). It implies that sharia stocks exchanges in Indonesia, United States, and Malaysia tend to be weak, while in Saudi Arabia it tends to be least-strong.
\end{abstract}

Keywords: sharia stocks price index, efficient market hypothesis

\section{Pendahuluan}

Bursa adalah pasar yang di dalamnya berjalan usaha jual beli saham yang melibatkan para broker sebagai perantara antara penjual dengan pembeli. Target bursa adalah menciptakan pasar simultan dan kontinu dimana penawaran dan permintaan serta orang-orang yang hendak melakukan perjanjian jual beli dipertemukan. Investasi di dalam Islam merupakan kegiatan ekonomi sekaligus kegiatan muamalah yang sangat dianjurkan agar harta yang dimiliki menjadi produktif dan bermanfaat bagi orang lain kecuali kegiatan tersebut bertentangan dengan ajaran Al-Qur'an dan Hadist. Bursa saham adalah salah satu sarana dalam melakukan investasi tersebut.

${ }^{1}$ Malik adalah Dosen di Jurusan Ilmu Ekonomi Fakultas Ekonomi (FE) Universitas Sebelas Maret (UNS). Email: malikcahyadin@yahoo.com, dan Devi adalah Staf Pusat Data Ekonomi dan Bisnis (PDBE) Fakultas Ekonomika dan Bisnis (FEB) UGM. Email: devi_milandari98@yahoo.com 
Pasar modal merupakan salah satu komponen penting di dalam perekonomian dunia saat ini. Banyak industri dan perusahaan yang menggunakan institusi pasar modal sebagai media untuk menyerap investasi dan media untuk memperkuat posisi keuangannya. Pasar modal bertindak sebagai penghubung antara para investor dengan perusahaan ataupun institusi pemerintah melalui perdagangan instrumen keuangan jangka panjang. Selama ini, pasar modal menjadi wadah ekonomi yang paling banyak menjalankan transaksi yang dilarang seperti bunga (riba), perjudian (gambling/maysir), penipuan, dan lain-lain.

Konsep bursa saham yang sesuai dengan prinsip syariah ialah dalam berbagi keuntungan dan kerugian, tetapi tidak semua bisnis yang terdaftar dalam bursa saham sesuai dengan prinsip syariah, isu ini merupakan tantangan dalam pengembangan pasar modal syariah sehingga dapat difahami bahwa pasar modal syariah adalah pasar modal yang dijalankan dengan konsep syariah, di mana setiap perdagangan surat berharga mentaati ketentuan transaksi sesuai dengan basis syariah. Oleh karena larangan dan batasan Islam pada bisnis-bisnis tertentu yang bertentangan dengan syariah, sampai tahun 1970 sejumlah besar masyarakat muslim tidak dapat terlibat dalam investasi di pasar modal.

Untuk memenuhi kepentingan pemodal yang ingin mendasarkan kegiatan investasinya berdasarkan kepada prinsip-prinsip syariah, maka di sejumlah bursa efek dunia telah disusun indeks yang secara khusus terdiri dari komponen sahamsaham yang tergolong kegiatan usahanya tidak bertentangan dengan prinsip syariah. Angka indeks atau sering disebut indeks saja pada dasarnya merupakan suatu angka yang dibuat sedemikian rupa sehingga dapat dipergunakan untuk melakukan perbandingan anatarkegiatan yang sama (produksi, ekspor, hasil penjualan, jumlah uang yang beredar dan lain sebagainya) dalam dua waktu yang berbeda. Demikian juga dengan indeks harga saham, indeks di sini akan membandingkan perubahan harga saham dari waktu ke waktu. Apakah suatu harga saham mengalami penurunan atau kenaikan dibandingkan dengan suatu waktu tertentu. Seperti dalam indeks lainnya dalam pengukuran indeks harga saham kita memerlukan juga dua macam waktu, yaitu waktu dasar dan waktu yang berlaku.

Ada beberapa negara yang telah menerapkan konsep syariah di pasar modal. Menurut Achsien (2000) pengembang pertama indeks syariah dan equity fund seperti reksadana adalah Amerika Serikat, setelah The Amana Fund diluncurkan The North American Islamic Trust sebagai equity fund pertama di tahun 1986, tiga tahun kemudian Dow Jones Index meluncurkan Dow Jones Islamic Market Index(DJIM). Sharia Supervisory Board (SSB) dari Dow Jones Islamic Market Index(DJIM) melakukan filterisasi terhadap saham-saham halal berdasarkan aktivitas bisnis dan rasio finansialnya.

Ada peristiwa penting pada tahun 2008 ini yang sangat berpengaruh di pasar modal dunia. Peristiwa tersebut adalah adanya krisis subprime mortgage, yaitu krisis yang disebabkan oleh banyaknya nasabah perusahan penerbit subprime 
mortgage gagal bayar karena The Fed menaikkan bunga kredit perumahaan yang ditujukan untuk orang miskin di Amerika tersebut. Kebutuhan likuiditas yang langka tersebut membuat para investor terpaksa menjual portofolionya, termasuk saham secara besar-besaran di seluruh dunia yang mengakibatkan terempasnya pasar modal dunia. Krisis subprime mortgage sangat merugikan investor keuangan dunia yang juga berinvestasi di pasar modal dan pasar uang Indonesia. Pukulan terbesar memang di pasar modal mengingat saham merupakan instrumen likuid begitu pula deposito. Kebutuhan likuiditas yang tinggi membuat mereka keluar dari pasar keuangan Indonesia.

Salah satu aliran besar dalam keuangan mengenai perilaku stock market adalah Efficient Market Hypothesis (EMH). Sebagian akademisi dipelopori oleh Eugene Fama berpendapat bahwa pasar adalah efisien dan rasional. Dengan didukung riset, mereka mengemukakan hipotesa bahwa harga pasar merupakan refleksi dari harga wajar saham dari waktu ke waktu. Saat harga pasar saham tinggi, artinya ekonomi sedang bullish, terjadi ekspansi ekonomi jadi, wajar harga saham menjadi mahal. Saat harga pasar jatuh, artinya ekonomi sedang bearish, terjadi perlambatan / resesi ekonomi jadi, wajar harga saham menjadi murah sehingga pendukung teori EMH tidak mengenal istilah overvalued dan undervalued.

Berdasarkan data perkembangan indeks harga saham syariah tahun 2005 - 2008 yang dipublikasikan oleh Bursa Efek Indonesia (BEI), Bloomberg dan yahoo finance nampak bahwa indeks harga saham syariah Indonesia (JII), Amerika Serikat (IMUS), Arab Saudi (SASEIDX) dan Malaysia (FTSEMY) cenderung berfluktuasi. Fluktuasi indeks harga saham syariah di masing-masing Negara tersebut dimungkinkan tidak terlepas dari adanya saling keterkaitan atau ketergantungan antar-negara.

Fenomena fluktuasi dan keterkaitan antar-indeks harga saham syariah Indonesia, Amerika Serikat, Arab Saudi dan Malaysia dapat dicermati pada Gambar 1 dan Tabel 1. Berdasarkan Gambar 1 dapat diketahui bahwa indeks harga saham syariah JII selama tahun 2005 sampai pertengahan 2008 cenderung meningkat dan menurun secara drastis pada akhir 2008. Hal ini terjadi sebagai akibat adanya goncangan di bursa saham dunia dan regional yang termanifestasikan ke dalam krisis keuangan global. Pada periode yang sama fluktuasi indeks harga saham juga terjadi di bursa saham syariah Amerika Serikat dan Malaysia. Kondisi yang relatif berbeda terjadi di bursa saham syariah Arab Saudi. Goncangan yang cukup signifikan di bursa saham syariah Arab Saudi yaitu pada periode tahun 2008 ini. 


\section{Gambar 1.Perkembangan Indeks Harga Sabam Syariah}

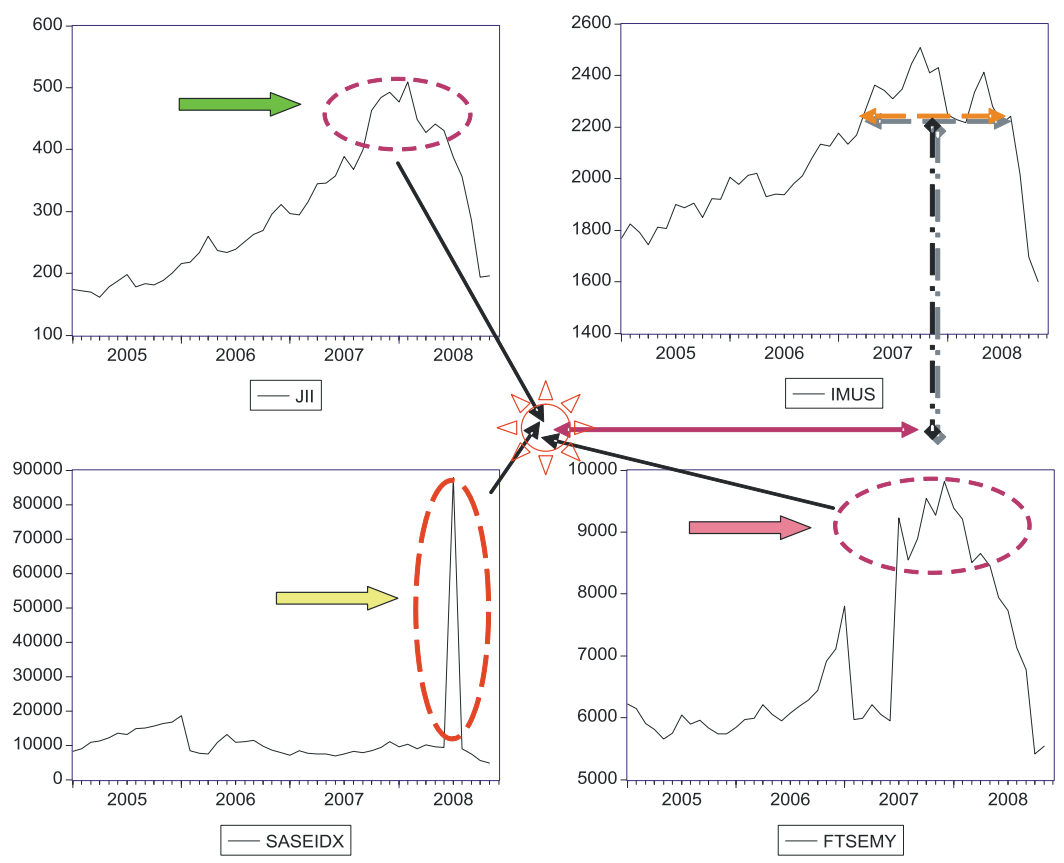

Sumber: BEI, Yahoo Finance dan Bloomberg.

Uraian dan gambaran tentang perkembangan dan keterkaitan antar-bursa saham syariah di dunia dapat dilihat pada hasil uji korelasi sederhana di Tabel 1. Berdasarkan hasil uji korelasi sederhana pada periode 2007 - 2008 dapat diketahui bahwa nilai korelasi antara JII - IMUS, JII - SASEIDX dan JII - FTSEMY masing-masing adalah sebesar 0,788; 0,099 dan 0,857. Sementara nilai korelasi antara SASEIDX - FTSEMY, SASEIDX - IMUS dan IMUS - FTSEMY masingmasing yaitu 0,061; 0,040 dan 0,646.

Tabel 1. Korelasi Sederhana Antar-Indeks Harga Saham Syariah, 2007 - 2008

\begin{tabular}{|l|c|c|c|c|}
\hline \multicolumn{1}{|c|}{ Variables } & JII & IMUS & SASEIDX & FSTEMY \\
\hline JII & 1.000 & 0.788 & 0.099 & 0.857 \\
\hline IMUS & 0.788 & 1.000 & 0.040 & 0.646 \\
\hline SASEIDX & 0.099 & 0.040 & 1.000 & 0.061 \\
\hline FTSEMY & 0.857 & 0.646 & 0.061 & 1.000 \\
\hline
\end{tabular}

Sumber: BEI, Yahoo Finance dan Bloomberg (diolah).

Berdasarkan uraian dan fenomena perkembangan bursa saham syariah 
di atas, maka penelitian tentang bentuk pasar saham syariah penting untuk dilakukan. Paper ini akan menjelaskan seperti apa bentuk pasar saham syariah di Indonesia, Amerika Serikat, Arab Saudi dan Malaysia dengan menggunakan metode Effcient Market Hypothesis (EMH).

\section{Batasan Masalah}

Penelitian untuk melihat bentuk bursa saham syariah Indonesia, Amerika Serikat, Arab Saudi dan Malaysia dengan menggunakan metode EMH menjadi menarik untuk dilakukan, karena dapat menentukan bentuk bursa saham syariah tersebut berdasarkan klasifikasi dalam metode EMH. Dimana dalam metode EMH terdapat tiga bentuk pasar yang dikaitkan dengan informasi (baik itu data maupun kebijakan) yang ada di pasar, yaitu: pasar dengan bentuk-lemah, bentuk-setengah-kuat, dan bentuk-kuat. Paper ini akan melihat bentuk bursa saham syariah Indonesia dan Amerika Serikat dengan pendekatan EMH pada indeks harga sahamnya (syariah).

\section{Tujuan}

Tujuan dari penelitian ini adalah;

1. Untuk mengetahui stasioneritas data indeks harga saham syariah sebagai dasar penentuan bentuk bursa saham syariah Indonesia, Amerika Serikat, Arab Saudi dan Malaysia.

2. Untuk mengetahui hubungan kausalitas indeks harga saham syariah Indonesia, Amerika Serikat, Arab Saudi dan Malaysia.

3. Untuk mengetahui korelasi antara bursa saham syariah Indonesia, Amerika Serikat, Arab Saudi dan Malaysia.

\section{Manfaat}

Adapun manfaat dari penelitian ini antara lain, yaitu;

1. Sebagai bahan referensi bagi regulator di bursa saham serta Pemerintah Indonesia, Amerika Serikat, Arab Saudi dan Malaysia. dalam pengelolaan dan perumusan kebijakan di pasar keuangan.

2. Menambah khasanah keilmuan dalam kajian ekonomi terutama terkait dengan bursa saham syariah dan penerapan analisis ekonometrika. 


\section{Kerangka Teori}

\section{A. Teori Efficient Market Hypothesis (EMH)}

Pasar yang efisien adalah pasar dimana harga semua sekuritas yang diperdagangkan telah mencerminkan semua informasi yang tersedia (Tandelilin, 2001). Pasar yang efisien ini disebut juga EMH.

Ada beberapa kondisi yang harus terpenuhi untuk tercapainya pasar yang efisien (Tandelilin, 2001):2

1. Ada banyak investor yang rasional dan berusaha untuk memaksimalkan keuntungan.

2. Semua pelaku pasar dapat memperoleh informasi pada saat yang sama dengan cara yang murah dan mudah

3. Informasi yang terjadi bersifat random

4. Investor bereaksi secara cepat terhadap informasi baru sehingga harga sekuritas akan berubah sesuai dengan perubahan nilai sebenarnya akibat informasi tersebut.

Adapun bentuk pasar yang efisien, yaitu (Tandelilin, 2001; Jones, 2002; dan Levi; 1996):

1. EMH Bentuk Lemah (Weak Form EMH)

Berarti semua informasi di masa lalu (historis) akan tercermin dalam harga yang terbentuk sekarang. Oleh karena itu, informasi historis tersebut tidak bisa lagi digunakan untuk memprediksi perubahan harga di masa yang akan datang karena sudah tercermin pada harga saat ini. Implikasinya bahwa investor tidak bisa memprediksi nilai pasar saham di masa datang dengan menggunakan data historis seperti yang dilakukan dalam analisis teknikal.

2. EMH Bentuk Setengah Kuat (Semistrong Form EMH)

Merupakan bentuk efisiensi pasar yang lebih komprehensif karena harga saham disamping dipengaruhi oleh data pasar juga dipengaruhi oleh semua informasi yang dipublikasikan. Pada pasar ini investor tidak dapat berharap mendapatkan return abnormal jika strategi perdagangan yang dilakukan hanya didasari oleh informasi yang telah dipublikasikan.

3. EMH Bentuk Kuat (Strong Form EMH)

Pada pasar ini semua informasi baik yang dipublikasikan maupun tidak dipublikasikan sudah tercermin dalam harga sekuritas saat ini. Dalam bentuk efisien kuat seperti ini tidak akan ada seorang investor pun yang bisa memperoleh return abnormal.

Tandelilin, Eduardus, 2001, Analisis Investasi dan Manajemen Portofolio, Yogyakarta, PT BPFE. Edisi Pertama. 


\section{B. EMH dan Pasar Valas/Surat Berharga}

Levi (1996) mempunyai perhatian yang cukup besar terhadap keterkaitan antara pasar yang efisien dengan kondisi pasar valas suatu negara. Argumentasinya didasarkan pada kondisi bahwa Efisiensi Pasar di pasar valas terkait dengan kemampuan nilai tukar suatu negara diprediksi dengan menggunakan nilai tukar spot. Dalam menentukan apakah nilai tukar forward yang diharapkan sesuai dengan ekspektasi nilai tukar spot yang akan datang dapat memunculkan pertanyaan bahwa seberapa relevan informasi yang digunakan di pasar menetukan nilai tukar forward sebagai prediktor dari nilai tukar spot yang di masa datang, atau faktor-faktor apa saja yang muncul di pasar yang bisa membantu dalam membuat prediksi?. Pertanyaan ini yang akhirnya dapat terkait dengan efisiensi pasar di pasar valas.

\section{VI.Metode Penelitian}

\section{A. Data dan Sumber Data}

Data yang digunakan dalam penelitian ini adalah data indeks harga saham syariah yang berasal dari website BEI (Bursa Efek Indonesia), yahoo finance dan Bloomberg. Periode data yang diteliti yaitu periode bulanan dari tahun $2005-$ 2008 (November). Indeks harga saham syariah Indonesia tercermin dalam JII (Jakarta Islamic Index). Indeks harga saham syariah Amerika Serikat tercermin dalam IMUS (Dow Jone Islamic Index Market US), indeks harga saham syariah Arab Saudi dan Malaysia masing-masing tercermin dalam SASEIDX (Tadawul All Share Index) dan FTSE Malaysia Emas (FTSEMY).

\section{B. Alat Analisis}

Alat analisis yang digunakan dalam penelitian ini menggunakan pendekatan EMH untuk mengetahui bentuk bursa saham syariah Indonesia dan Amerika Serikat. Adapun pengujian atau prosedur analisis data berdasarkan prosedur ekonometrika pada data runtun waktu, yaitu; uji stasioneritas dan uji kausalitas Granger. Selain itu, dalam penelitian ini juga akan dilakukan uji korelasi sederhana.

\section{Analisis dan Diskusi}

Penelitian tentang bursa saham syariah menjadi bagian yang tidak terlepas dari perkembangan ekonomi islami. Tidak dapat dipungkiri bahwa perkembangan praktik-praktik ekonomi islami masih lebih didominasi oleh aktivitas sektor keuangan. Ketika perekonomian dunia terhempas karena gejolak keuangan di 
Amerika Serikat, yang termanifestasikan dalam krisis keuangan global, merupakan suatu tantangan tersendiri bagi ekonom-ekonom dan pegiat ekonomi islami untuk memberikan solusi aplikatif yang komprehensif. Sebagai salah satu bagian dari upaya untuk mendalami perkembangan dan kondisi riil pasar keuangan syariah (pasar saham syariah) dunia, maka penelitian ini dilakukan.

Fokus dari penelitian ini adalah mengetahui dan menganalisis bentuk pasar saham syariah dengan melihat perkembangan indeks harga sahamnya. Tahap pertama yang dilakukan adalah melakukan uji stasioneritas data indeks harga saham syariah JII (Indonesia), IMUS (Amerika Serikat), SASEIDX (Arab Saudi) dan FTSEMY (Malaysia). Uji stasioneritas data dalam penelitian ini dilakukan dengan menggunakan metode ADF (Augmented Dickey-Fuller) dan PP (Phillips-Perron).

Hasil uji stasioneritas data JII menunjukkan bahwa data stasioner pada 1st difference (Tabel 2). Ini mengindikasikan bahwa bentuk pasar saham syariah Indonesia dikategorikan ke dalam bentuk pasar lemah. Sesuai dengan teori EMH bahwa pasar dengan bentuk lemah menunjukkan indikasi harga saham syariah pada saat ini lebih disebabkan oleh informasi yang terjadi pada periode-periode sebelumnya.

Tabel 2. Uji Stasioneritas Indeks Harga Saham Syariab Indonesia

\begin{tabular}{|c|l|l|}
\hline \multicolumn{1}{|c|}{ JII } & \multicolumn{1}{c|}{ ADF } & \multicolumn{1}{c|}{ PP } \\
\hline A. Uji Stasioneritas Pada Level & & \\
\hline Uji Stasioneritas dengan Intercept & Tidak Stasioner & Tidak Stasioner \\
\hline Uji Stasioneritas dengan Intercept dan Trend & Tidak Stasioner & Tidak Stasioner \\
\hline B. Uji Stasioneritas Pada 1st Difference & & \\
\hline Uji Stasioneritas dengan Intercept & $-3.212206(1) \mathrm{a}$ & $-4.482651(2) \mathrm{a}$ \\
\hline Uji Stasioneritas dengan Intercept dan Trend & $-3.620535(1) \mathrm{b}$ & $-4.824066(2) \mathrm{a}$ \\
\hline $\begin{array}{l}\text { Keterangan; (a) stasioner pada nilai kritis 5\% dan (b) stasioner pada nilai kritis 10\%. Panjang } \\
\text { lag yang digunakan untuk menguji stasioneritas data terlihat di dalam tanda kurung (). } \\
\text { Penentuan panjang lag dengan menggunakan nilai terkecil dari AIC dan SIC. Uji stasioneritas } \\
\text { di atas menggunakan metode ADF dan PP. }\end{array}$ \\
\hline
\end{tabular}

\section{Sumber: Hasil analisis}

Tabel 3 menjelaskan hasil uji stasioneritas data indeks harga saham syariah Amerika Serikat (IMUS). Kondisi stasioneritas data IMUS tidak jauh berbeda dengan JII. Periode kelambanan (lag) antara IMUS dan JII juga tidak jauh berbeda khususnya dengan metode ADF. Dengan demikian, dapat dikatakan bahwa pasar saham syariah Amerika Serikat berbentuk lemah. Sebagai bursa yang menjadi transaksi berbagai investor di dunia, bursa saham di Amerika Serikat pun masih memanfaatkan informasi masa lalu untuk membentuk tingkat harga saham syariah saat ini. 
Tabel 3. Uji Stasioneritas Indeks Harga Sabam Syariah Amerika Serikat

\begin{tabular}{|c|l|l|}
\hline \multicolumn{1}{|c|}{ IMUS } & \multicolumn{1}{c|}{ ADF } & \multicolumn{1}{c|}{ PP } \\
\hline A.Uji Stasioneritas Pada Level & & \\
\hline Uji Stasioneritas dengan Intercept & Tidak Stasioner & Tidak Stasioner \\
\hline Uji Stasioneritas dengan Intercept dan Trend & Tidak Stasioner & Tidak Stasioner \\
\hline B. Uji Stasioneritas Pada 1 $1^{\text {st }}$ Difference & & \\
\hline Uji Stasioneritas dengan Intercept & $-3.245327(1)^{\mathrm{b}}$ & $-4.816492(1)^{\mathrm{a}}$ \\
\hline Uji Stasioneritas dengan Intercept dan Trend & $-3.815871(1)^{\mathrm{b}}$ & $-5.221511(3)^{\mathrm{a}}$ \\
\hline $\begin{array}{l}\text { Keterangan; (a) stasioner pada nilai kritis 5\% dan (b) stasioner pada nilai kritis 10\%. Panjang } \\
\text { lag yang digunakan untuk menguji stasioneritas data terlihat di dalam tanda kurung ( ). } \\
\text { Penentuan panjang lag dengan menggunakan nilai terkecil dari AIC dan SIC. Uji stasioneritas } \\
\text { di atas menggunakan metode ADF dan PP. }\end{array}$ \\
\hline
\end{tabular}

\section{Sumber: Hasil analisis}

Kondisi stasioneritas harga saham syariah Arab Saudi (SASEIDX) relatif berbeda dengan JII dan IMUS. SASEIDX tidak hanya stasioner pada 1st difference, tetapi juga pada level (Tabel 4). Ini dapat dikatakan bahwa sebenarnya pasar saham syariah Arab Saudi termasuk dalam kategori semi-kuat. Dalam pasar saham dengan bentuk semi-kuat informasi yang membentuk harga saham syariah pada saat ini tidak hanya informasi di masa lalu tetapi juga informasi yang berjalan.

Jika dianalisis lebih jauh, dimungkinkan keputusan investor untuk melakukan transaksi saham syariah di bursa saham syariah Arab Saudi memanfaatkan semua informasi yang ada di bursa saham syariah tersebut. Perilaku investor seperti ini diharapkan dapat mengurangi perilaku spekulatif yang terjadi di bursa saham untuk menentukan tingkat harga saham yang terjadi (berlaku). Konsep menjauhi praktik-praktik spekulatif dalam transaksi muamalah merupakan salah satu koridor dalam ekonomi islami (ajaran Islam) yang tidak dapat ditawar. Mengurangi praktik-praktik spekulasi di pasar keuangan (saham) akan mengarahkan perilaku dan mekanisme transaksi di pasar tersebut lebih clear dan tidak saling menipu satu sama lain. Prinsip informasi yang simetris seharusnya dapat diterapkan secara sungguh-sungguh di bursa saham (pasar keuangan) syariah. 
Tabel 4. Uji Stasioneritas Indeks Harga Saham Syariab Arab Saudi

\begin{tabular}{|c|l|l|}
\hline \multicolumn{1}{|c|}{ SASEIDX } & \multicolumn{1}{c|}{ AD } & \multicolumn{1}{c|}{ PP } \\
\hline A. Uji Stasioneritas Pada Level & & \\
\hline Uji Stasioneritas dengan Intercept & $-3.511779(3)^{\mathrm{a}}$ & $-6.581881(3)^{\mathrm{a}}$ \\
\hline Uji Stasioneritas dengan Intercept dan Trend & $-3.840336(2)^{\mathrm{b}}$ & $-6.515162(3)^{\mathrm{a}}$ \\
\hline B. Uji Stasioneritas Pada 1 st $^{\mathrm{a}}$ Difference & & \\
\hline Uji Stasioneritas dengan Intercept & $-5.635369(3)^{\mathrm{a}}$ & $-11.62073(1)^{\mathrm{a}}$ \\
\hline Uji Stasioneritas dengan Intercept dan Trend & $-5.690734(3)^{\mathrm{a}}$ & $-11.49561(1)^{\mathrm{a}}$ \\
\hline $\begin{array}{l}\text { Keterangan; (a) stasioner pada nilai kritis 5\% dan (b) stasioner pada nilai kritis 10\%. Panjang } \\
\text { lag yang digunakan untuk menguji stasioneritas data terlihat di dalam tanda kurung ( ). } \\
\text { Penentuan panjang lag dengan menggunakan nilai terkecil dari AIC dan SIC. Uji stasioneritas } \\
\text { di atas menggunakan metode ADF dan PP. }\end{array}$ \\
\hline
\end{tabular}

\section{Sumber: Hasil analisis}

Tabel 5 menjelaskan hasil uji stasioneritas indeks harga saham syariah Malaysia (FTSEMY). Hasil uji stasioneritas data FTSEMY sudah stasioner pada 1st difference. Dengan stasioner pada 1st difference, maka dapat dikatakan bahwa bursa saham syariah Malaysia termasuk dalam kategori pasar saham bentuklemah.

\section{Tabel 5. Uji Stasioneritas Indeks Harga Sabam Syariab Malaysia}

\begin{tabular}{|c|l|l|}
\hline \multicolumn{1}{|c|}{ FTSEMY } & \multicolumn{1}{c|}{ ADF } & \multicolumn{1}{c|}{ PP } \\
\hline A.Uji Stasioneritas Pada Level & & \\
\hline Uji Stasioneritas dengan Intercept & Tidak Stasioner & Tidak Stasioner \\
\hline Uji Stasioneritas dengan Intercept dan Trend & Tidak Stasioner & Tidak Stasioner \\
\hline B. Uji Stasioneritas Pada 1 ${ }^{\text {st }}$ Difference & & \\
\hline Uji Stasioneritas dengan Intercept & $-4.463218(1)^{\mathrm{a}}$ & $-7.622722(3)^{\mathrm{a}}$ \\
\hline Uji Stasioneritas dengan Intercept dan Trend & $-4.574672(1)^{\mathrm{a}}$ & $-7.67647(3)^{\mathrm{a}}$ \\
\hline $\begin{array}{l}\text { Keterangan; (a) stasioner pada nilai kritis 5\% dan (b) stasioner pada nilai kritis 10\%. Panjang } \\
\text { lag yang digunakan untuk menguji stasioneritas data terlihat di dalam tanda kurung ( ). } \\
\text { Penentuan panjang lag dengan menggunakan nilai terkecil dari AIC dan SIC. Uji stasioneritas } \\
\text { di atas menggunakan metode ADF dan PP. }\end{array}$ \\
\hline
\end{tabular}

\section{Sumber: Hasil analisis}

Setelah kita melakukan uji stasioneritas data, perlu juga dianalisis bagaimana pola dan perkembangan indeks harga saham syariah di Indonesia, Amerika Serikat, Arab Saudi dan Malaysia. Dengan menggunakan distribusi kumulatif dapat diketahui bahwa secara umum pergerakan indeks harga saham syariah cenderung meningkat (Gambar 2). Peningkatan indeks harga saham syariah ini diharapkan dapat mencerminkan semakin membaiknya kinerja bursa saham syariah dunia. Yang perlu diwaspadai adalah jangan sampai peningkatan indeks harga saham syariah ini akan menjadi bencana keuangan sebagaimana yang terjadi di bursa saham (keuangan) konvensional saat ini. 


\section{Gambar 2. Distribusi Kumulatif Indeks Harga Saham Syariah}
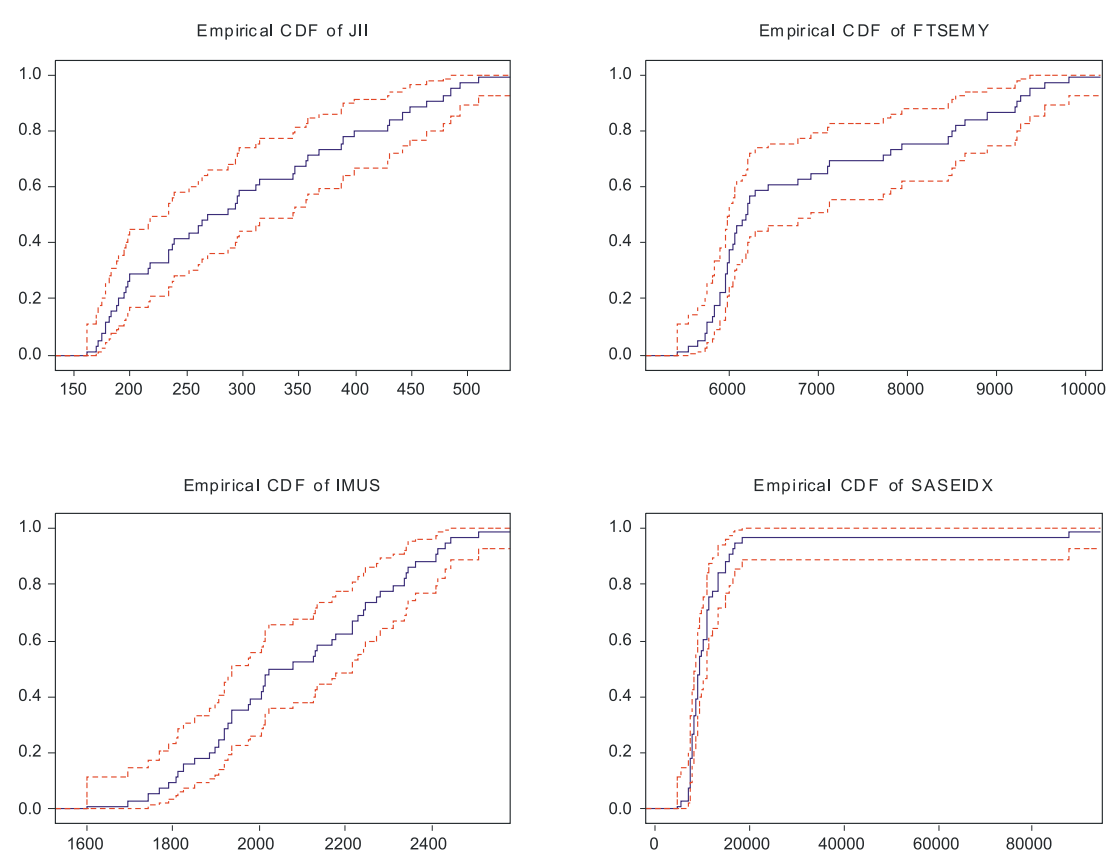

Sumber: BEI, Yahoo Finance dan Bloomberg (diolah).

Pengujian berikutnya yang perlu dilakukan adalah uji kausalitas Granger. Uji kausalitas ini dilakukan untuk mengetahui ada tidaknya kausal antar-indeks harga saham syariah di dunia. Tabel 6 menunjukkan hasil uji kausalitas Granger JII, IMUS, SASEIDX dan FTSEMY. Pada kasus kausal antara JII dan IMUS nampak bahwa pada lag 1 IMUS berpengaruh terhadap JII. Artinya bahwa perilaku atau kondisi bursa saham syariah Amerika Serikat akan berpengaruh terhadap perilaku atau kondisi di bursa saham syariah Indonesia. Kondisi ini perlu diwaspadai oleh kedua regulator di bursa saham (sektor keuangan) untuk melakukan pengawasan serta pengambilan kebijakan yang hati-hati serta kredibel.

Sebagai sebuah negara sedang berkembang, Indonesia relatif akan tergantung dan terguncang apabila bursa saham syariah di Amerika Serikat bergejolak. Sebagaimana telah kita ketahui bahwa gejolak di sektor keuangan, baik langsung maupun tidak langsung, akan berdampak pada sektor bisnis (riil). Ketidakstabilan dan kemerosotan sektor bisnis karena gejolak sektor keuangan akan mengganggu kestabilan dan target-target pembangunan ekonomi di setiap negara terutama negara sedang berkembang. Kata kunci yang harus diterapkan oleh semua pelaku di bursa saham (pasar keuangan) syariah adalah konsisten (istiqomah) dalam menerapkan prinsip-prinsip muamalah (sesuai dengan ajaran Islam). 
Malik Cahyadin \& Devi Oktaviana Milandari: Analisis ...

Tabel 6. Uji Kausalitas Granger

\begin{tabular}{|l|l|l|l|}
\hline \multicolumn{1}{|c|}{ Items } & \multicolumn{1}{c|}{ Lag $\mathbf{1}$} & \multicolumn{1}{c|}{ Lag 2 } & \multicolumn{1}{c|}{ Lag $\mathbf{3}$} \\
\hline IMUS does not Granger Cause JII & Sig. & Tidak & Tidak \\
\hline JII does not Granger Cause IMUS & Tidak & Tidak & Tidak \\
\hline FTSEMY does not Granger Cause JII & Tidak & Tidak & Tidak \\
\hline JII does not Granger Cause FTSEMY & Sig. & Sig. & Sig. \\
\hline SASEIDX does not Granger Cause JII & Tidak & Sig. & Sig. \\
\hline JII does not Granger Cause SASEIDX & Tidak & Tidak & Tidak \\
\hline
\end{tabular}

\section{Sumber: Hasil analisis}

Dari hasil uji kausalitas Granger juga dapat diketahui bahwa JII berpengaruh pada FTSEMY baik lag 1, 2 maupun 3. Ini berarti bahwa ada kaitan antara perilaku bursa saham syariah di Indonesia dan Malaysia. Sebagai negara yang bertetangga dan serumpun seyogyanya kedua negara menjalin kerjasama dalam pengembangan bursa saham syariah.

Di lain sisi, indeks harga saham syariah SASEIDX berpengaruh terhadap JII pada lag 2 dan 3. Dengan kata lain, bursa saham syariah Arab Saudi berpengaruh terhadap bursa saham syariah Indonesia. Meskipun pengaruh tersebut pada 2 periode sebelumnya, tetapi jalinan kerjasama yang saling menguntungkan antara Indonesia dan Arab Saudi harus dilakukan. Pengembangan bursa saham syariah di Indonesia dan Arab Saudi tidak hanya sebatas pengembangan jenis transaksi tetapi peningkatan volume transaksi.

Tabel 7 menunjukkan hasil uji korelasi antara indeks harga saham syariah di Indonesia, Amerika Serikat, Arab Saudi dan Malaysia. Hasil dari uji korelasi ini tidak jauh berbeda dengan uji kausalitas Granger. Pada dasarnya, bursa saham syariah di suatu negara mempunyai keterkaitan dengan bursa saham syariah di negara lain baik secara langsung maupun tidak langsung. Nilai korelasi antara JII - IMUS, JII - SASEIDX dan JII - FTSEMY masing-masing adalah sebesar 0,903; 0,031 dan 0,897. Besarnya nilai korelasi antara JII - IMUS dan JII - FTSEMY mengindikasikan ada korelasi yang kuat dan positif antara bursa saham syariah Indonesia dengan Amerika Serikat dan Malaysia.

Sementara itu, nilai korelasi antara SASEIDX - IMUS dan SASEIDX FTSEMY masing-masing yaitu 0,009 dan 0,023. Nilai korelasi antara FTSEMY - IMUS adalah 0,789. Nilai korelasi antara FTSEMY - IMUS ini relatif besar yang mengindikasikan adanya korelasi yang relatif kuat antara bursa saham syariah Malaysia dan Amerika Serikat. Yang menarik dari hasil uji korelasi ini adalah bahwa korelasi antara bursa saham syariah Arab Saudi (SASEIDX) dan Amerika Serikat (IMUS) sangat lemah. Penjelasan akan fenomena ini cukup penting untuk dijelaskan. Namun demikian, karena penelitian ini tidak membahas secara khusus antara bursa saham syariah Arab Saudi dan Amerika Serikat, maka penelitian selanjutnya disarankan untuk mengkajinya lebih lanjut. 
Tabel 7. Uji Korelasi

\begin{tabular}{|l|l|l|l|l|}
\hline \multicolumn{5}{|c|}{ Common Correlation Matrix } \\
\hline \multicolumn{1}{|c|}{ Variables } & \multicolumn{1}{c|}{ FTSEMY } & \multicolumn{1}{c|}{ IMUS } & \multicolumn{1}{c|}{ JII } & SASEIDX \\
\hline FTSEMY & 1.000 & 0.789 & 0.897 & 0.023 \\
\hline IMUS & 0.789 & 1.000 & 0.903 & 0.009 \\
\hline JII & 0.897 & 0.903 & 1.000 & 0.031 \\
\hline SASEIDX & 0.023 & 0.009 & 0.031 & 1.000 \\
\hline
\end{tabular}

Sumber: Hasil analisis

Gambar 3 mengindikasikan sebaran data dan tren antar-indeks harga saham syariah. Secara umum dapat dikatakan bahwa tren antar-indeks harga saham syariah tersebut cenderung positif. Perilaku sebaran data yang cenderung menjauhi garis trennya adalah IMUS - SASEIDX dan SASEIDX - JII. Jika dikaitkan sebaran data dan tren ini dengan hasil uji korelasi ada indikasi yang sama bahwa perilaku bursa saham syariah Arab Saudi tidak terkait secara langsung dengan bursa saham syariah Amerika Serikat dan Indonesia.

\section{Gambar 3. Scatter Plot (dengan Tren) Indeks Harga Saham Syariab}
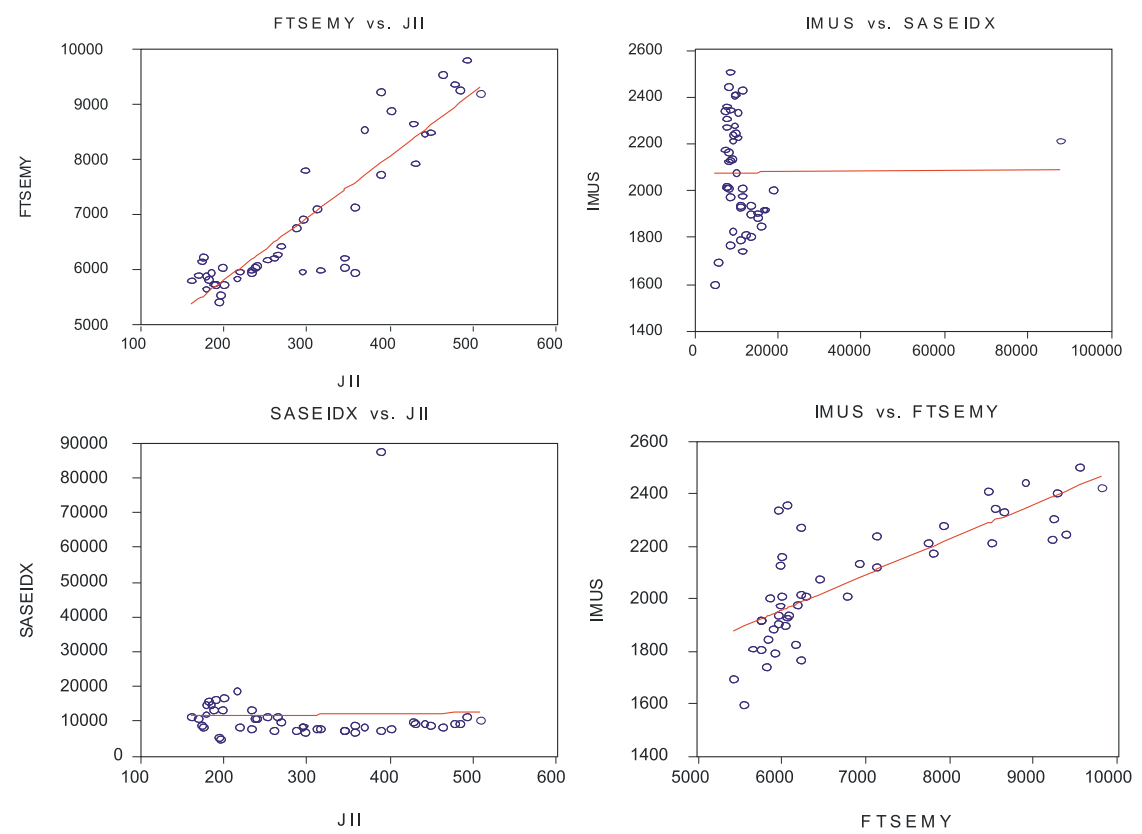

Sumber: BEI, Yahoo Finance dan Bloomberg (diolah). 


\section{Penutup}

Berdasarkan hasil uji stasioneritas data indeks harga saham syariah JII, IMUS, SASEIDX dan FTSEMY dapat disimpulkan bahwa bursa saham syariah di Indonesia, Amerika Serikat dan Malaysia berbentuk-lemah sedangkan di Arab Saudi berbentuk-semi-kuat. Dari uji kausalitas Granger terlihat bahwa bursa saham syariah Amerika Serikat mempengaruhi bursa saham syariah Indonesia. Selain itu, bursa saham syariah Indonesia mempengaruhi bursa saham syariah Malaysia dan bursa saham syariah Arab Saudi mempengaruhi bursa saham syariah Indonesia. Korelasi antara bursa saham syariah Indonesia dan Malaysia dengan Amerika Serikat bersifat kuat dan positif.

Aspek yang perlu diperhatikan oleh semua pelaku atau pihak di bursa saham (pasar keuangan) syariah adalah menjalankan prinsip-prinsip muamalah (ajaran Islam) secara konsisten (istiqomah). Menjauhi praktik-praktik spekulasi dan menciptakan informasi yang simetris dalam setiap transaksi. Ini dilakukan untuk menghindari fenomena booble dalam pasar keuangan yang berdampak pada terpersoknya perekonomian ke dalam krisis keuangan atau resesi ekonomi sebagaimana terjadi saat ini.

Kelemahan yang perlu diperbaiki dalam paper ini antara lain bahwa analisis untuk mengungkapkan bentuk pasar, pola dan perkembangan bursa saham syariah relatif sederhana. Untuk itu, diharapkan ada berbagai metode analisis yang lebih akurat dan komprehensif. Akhirnya, semoga hasil studi dapat bermanfaat bagi semua pihak terutama dalam pengembangan studi empiris keuangan Islam.

\section{DAFTAR PUSTAKA}

Anonymous, undated,"Efficiency of The Foreign Exchange Market of Papua New Guinea During The Recent Float".

Jones, Charles P., 2002, Investments Analysis and Management, USA, John Wiley $\&$ Sons. Eight Edition.

Froyen, Richard T., 2002, Macroeconomics; Theory and Policies, USA, PrenticeHall International Inc. Seven Edition.

Gujarati, Damodar N., 1995, Basic Econometrics, Singapore, McGraw-Hill.

Levi, Maurice D., 1996, International Finance; the markets financial management of multinational business, Singapore, McGraw-Hill. Third Edition.

Tandelilin, Eduardus, 2001, Analisis Investasi dan Manajemen Portofolio, Yogyakarta, PT BPFE. Edisi Pertama.

Widarjono, Agus, 2005, Ekonometrika Teori dan Aplikasi; untuk ekonomi dan bisnis, Yogyakarta, EKONISIA.

www.idx.co.id

www.finance.yahoo.com

www.bloomberg.com 